\title{
Autologous anti-SOX2 antibody responses reflect intensity but not frequency of antigen expression in small cell lung cancer
}

\author{
Sukru Atakan ${ }^{1}$, Hulya Bayiz², Serpil Sak ${ }^{3}$, Alper Poyraz ${ }^{1}$, Burcak Vural ${ }^{5}$, Azmi Serhat Yildirim ${ }^{1}$, Funda Demirag ${ }^{4}$ \\ and Ali Osmay Gure ${ }^{1 *}$
}

\begin{abstract}
Background: Anti-SOX2 antibody responses are observed in about 10 to $20 \%$ of small cell lung cancer (SCLC) patients. The aim of this study was to determine whether such responses reflect a particular pattern of SOX2 protein expression in the tumor and whether this pattern associates with clinical outcome.

Methods: Paraffin embedded tumor tissues, obtained from SCLC patients who had no evidence of paraneoplastic autoimmune degeneration, were evaluated for SOX2 expression by immunohistochemistry for both intensity and extent of staining. Sera from the same patients were tested for autologous antibodies against recombinant SOX2 by enzyme-linked immunosorbent assay (ELISA). Correlates between overall survival and various clinical parameters including SOX2 staining and serology were determined.

Results: SOX2 protein expression was observed in tumor tissue in $89 \%$ of patients. Seventeen patients (29\%) were seropositive for SOX2 antibodies and, in contrast to SOX2 staining, the presence of antibody correlated with limited disease stage $(p=0.05)$. SOX2 seropositivity showed a significant association with the intensity of SOX2 staining in the tumor $(p=0.02)$ but not with the frequency of SOX2 expressing cells.

Conclusion: Anti-SOX2 antibodies associate with better prognosis (limited stage disease) while SOX2 protein expression does not; similar to reports from some earlier studies. Our data provides an explanation for this seemingly contrasting data for the first time as SOX2 antibodies can be observed in patients whose tumors contain relatively few but strongly staining cells, thus supporting the possible presence of active immune-surveillance and immune-editing targeting SOX2 protein in this tumor type.
\end{abstract}

Keywords: Tumor immunology, Cancer stem cells, Autologous antibody responses, Tumor antigens, Lung cancer, Immunohistochemistry, Autologous antibodies, Cancer stem-cells

\section{Background}

SRY-homology box group B1 genes (SOX1, SOX2, SOX3) are known to function in neural plate, gut and lung development [1,2]; and SOX2 has a role in maintaining the pluripotent stem cell phenotype [3]. In line with these facts, SOX2 protein expression was shown to be an independent marker for worse outcome in early stage lung adenocarcinoma [4] and to associate with tumor aggression and higher grade in lung cancer [5]. Another study, however, correlated

\footnotetext{
* Correspondence: agure@bilkent.edu.tr

'Department of Molecular Biology and Genetics, Bilkent University, Ankara 06800, Turkey

Full list of author information is available at the end of the article
}

SOX2 expression with lower grade and with better outcome in squamous cell carcinoma of the lung [6], and a recent study found a relation between SOX2 expression and advanced disease, as well as worse overall survival in SCLC [7]. These seemingly conflicting results could be due to tumor type specific behavior of $S O X 2$, or technical reasons but they could also be due to presence of unacknowledged confounding prognostic factors. We hypothesized that such a factor could be the presence of an autologous immune response against SOX2. Cancer patients can mount antibody responses against a wide range of tumor antigens [8]. SOX Group B1 proteins have been shown to elicit some of the highest titered autologous anti-tumor antibody responses 
observed to date [9]. Despite the high-titered responses, several studies showed no association between immune responses to SOX proteins and improved outcome [10,11], although others did [12,13]. In this line, how anti-SOX2 antibody responses relate to SOX2 protein expression in lung cancer remains unanswered. Since anti-SOX2 antibodies are most frequently found in patients with small cell carcinoma of the lung (SCLC), we asked if immunity against SOX2 was related to its protein expression, and if either related to clinical parameters determining outcome in SCLC.

\section{Methods}

\section{Patient and control population}

The study cohort consisted of 59 patients with pathologically confirmed SCLC diagnosed between October 2007 and January 2009. All patients gave informed consent and the study was approved by the ethical board of the Atatürk Chest Diseases and Chest Surgery Education and Research Hospital, Ankara, Turkey. All samples were anonymized before analysis. None of the patients had neurological symptoms or evidence of paraneoplastic disease (PND) within the follow-up period. The clinical data obtained from patients at the time of diagnosis included age, gender, tumor stage, serum alkaline phosphatase (AP), and lactate dehydrogenase levels (LDH). All patients received chemotherapy with or without concurrent and sequential radiotherapy. Survival data was available for all patients. Follow-up times ranged from 0.2 to 44.7 months with a median of 8.68 months. Sera from 157 age-matched healthy controls were obtained after informed consent at the Capa Chest Diseases and Chest Surgery Education and Research Hospital of İstanbul, Turkey.

\section{Enzyme-linked immunosorbent assay}

Serum samples were obtained from all 59 patients, collected at the time of diagnosis, between October 2007 and January 2009 and stored at $-70^{\circ} \mathrm{C}$. SOX2 and two control proteins (EBV-p18 and DHFR) were expressed and purified using the prokaryotic $\mathrm{pQE}$ expression system (Qiagen Inc., Valencia, CA, USA). All constructs contained cDNA corresponding to the full ORF of each gene. Ninety-six well Immulon $4 \mathrm{HBX}$ plates (Thermo Scientific, Lafayette, CO, USA) were coated with $0.2 \mu \mathrm{g}$ / $\mathrm{ml}$ antigen at $4^{\circ} \mathrm{C}$ for 16 hours. Plates were blocked with $5 \%$ non-fat milk in PBS. Patient sera were added to plates at two dilutions $(1: 400,1: 1600)$ and incubated for $2 \mathrm{~h}$ at $37^{\circ} \mathrm{C}$ and subsequently with goat antihuman IgG - AP conjugate (Jackson Immunoresearch Laboratories Inc., West Grove, PA, USA) at a dilution of 1:5000. The color reaction was read with an ELISA plate reader (BioTek Instruments, Inc., Winooski, VT, USA). Each experiment was repeated twice. A sample was considered seropositive if the average of OD405 values for the two dilutions for a given sample was above the mean plus 2 standard deviation of that obtained for healthy control serum (corresponding to an OD405 value of 1,799$)$. Six control sera $(3.8 \%)$ were seropositive (Additional file 1: Figure S1). DHFR was used as negative and EBV p18 as positive controls. OD values obtained for anti-p18 antibodies from patients and controls were not statistically different.

\section{Western analysis of SOX2 seroreactivity}

One hundred nanograms per well of recombinant SOX2 protein was separated by $12 \%$ SDS-PAGE under denaturing conditions and transferred to Immobilon-P PVDF membranes (Milipore, St. Charles, MO, USA) using the BioRad semi-dry transfer system. The membranes were then blocked in 5\% non-fat milk and incubated with patient serum diluted at 1:3000 for 16 hours at $4^{\circ} \mathrm{C}$, after which they were washed in TBS$\mathrm{T}$ and incubated with goat anti-human IgG (Fc-specific)-HRP (Sigma, St. Louis, MO, USA ) for 2 hours. Immunoreactive protein was visualized using ECL-Plus Western Blotting system (GE Healthcare, Buckinghamshire, UK). Mouse anti-human SOX2 monoclonal antibody (R\&D Systems, Minneapolis, MN, USA) was used as a positive control.

\section{Immunohistochemistry}

Formalin-fixed paraffin embedded tumor tissues from all patients, obtained at the time of diagnosis, were retrospectively evaluated by IHC. Fifty five of 59 tissues had sufficient tumor tissue for a reliable evaluation. Tissues were sectioned at $4 \mu \mathrm{m}$, placed on positively charged slides and stained using a Ventana Benchmark LT automatic immunostainer (Ventana Medical Systems, Tuscon, AZ, USA). A range of dilutions of the primary antibody as well as various incubation times and temperatures were tested for optimization. Monoclonal mouse anti-human SOX2 primary antibody (MAB2018, R\&D Systems, Minneapolis, MN, USA) was used to stain sections at a 1:25 dilution for 40 minutes. The iViewT DAB Detection Kit (Ventana Medical Systems, Tuscon, AZ, USA), with standard CC1 pretreatment was used for detection. IHC staining was estimated by microscopy as the frequency (percentage) of stained cells as well as by the intensity of staining (graded from 0 to 3 ). H-scores were calculated as described previously [14]. All samples were evaluated independently by two pathologists (SS and FD). The NTERA-2 cell line was used as a positive control and for optimization experiments. A normal tissue (sausage) block was used as a negative control and was included in every run. 


\section{Statistical analysis}

Distribution of anti-SOX2 antibody or SOX2 staining in each of age, sex, stage, AP and LDH categories were examined using frequency tables, and differences were evaluated with two sided chi-square tests. Overall survival was defined as the time from diagnosis to death or date of last follow-up. Data for patients that were alive at the last contact were censored. SOX2 protein or antibody effects on survival were estimated by Kaplan-Meier method and the log-rank test was used to compare survival across groups. All data were dichotomized as indicated in the tables and analyzed as categorical variables. All $P$ values were two-sided. All analyses were performed using GraphPad Prism version 6.00, (GraphPad Software, San Diego California USA), or the Statistical Package for the Social Sciences, version 19 (SPSS Inc., Chicago, IL).

\section{Results}

The clinical features of the 59 SCLC patients and their association with overall survival are shown in Table 1. Median age was 64 years (range, 44 to 85 years). All except 6 patients were male. Cut-off values for AP and LDH were $70 \mathrm{IU}$ and $200 \mathrm{IU}$, respectively [15,16]. Fifty one percent of the patients had limited stage disease at the time of diagnosis. Limited disease stage was associated with longer overall survival $(p=0.03)$. Seventeen of 59 patients $(29 \%)$ had antibodies against SOX2 (Table 2), as determined by ELISA using recombinant SOX2 protein, and confirmed by Western analysis (Figure 1 and Additional file 1: Figure S1). We did not observe an association of antibodies with overall survival (Additional file 1: Figure S2). However, SOX2 antibodies were more often present in serum from patients with limited stage disease: while 12 of 28 patients with limited stage had SOX2 antibodies, only 5 patients with extensive disease were seropositive $(\mathrm{p}=$ 0.05 ) (Table 3 ). We could not find a statistically significant correlation between SOX2 seropositivity and any other clinical parameter. Positive staining by immunohistochemistry for SOX2 protein was observed in 42 of 55 tumors and was primarily nuclear and occasionally cytoplasmic in character, ranging from very intense to weak, with frequencies between 2\% to $90 \%$ (Figure 2 and Table 2). Although in most cases only some cells expressed SOX2, the intensity of staining for those cells within a given tumor was always of similar intensity. We found no statistically significant correlations between frequency or intensity of SOX2 protein expression and any of the clinical features. We then asked whether SOX2 antibodies correlated with SOX2 protein expression in tumor tissues. We found no statistically significant association between the frequency of SOX2 staining and SOX2 antibody presence, when
Table 1 Clinical features and SOX2 antibody and protein staining characteristics of SCLC patients

\begin{tabular}{|c|c|c|c|c|}
\hline & & $\mathrm{n}$ & $\begin{array}{l}\text { Median survival } \\
\text { (months) }\end{array}$ & P (log rank) \\
\hline \multirow[t]{3}{*}{ Age } & $61(44-78)$ & & & \\
\hline & $<60$ & 24 & 10.36 & 0.76 \\
\hline & $\geq 60$ & 35 & 7.1 & \\
\hline \multirow[t]{4}{*}{$\mathrm{LDH}$} & $\begin{array}{l}193 \mathrm{IU} / \mathrm{L} \\
(133-380)\end{array}$ & & & \\
\hline & $<200$ & 30 & 10.75 & 0.36 \\
\hline & $\geq 200$ & 25 & 8.86 & \\
\hline & $U^{*}$ & 4 & & \\
\hline \multirow[t]{4}{*}{$A P$} & $\begin{array}{l}93 \mathrm{IU} / \mathrm{L} \\
(50-171\end{array}$ & & & \\
\hline & $<70$ & 14 & 3.97 & 0.47 \\
\hline & $\geq 70$ & 44 & 8.68 & \\
\hline & $U$ & 1 & & \\
\hline \multirow[t]{3}{*}{ Stage } & Limited & 28 & 10.36 & 0.03 \\
\hline & Extensive & 27 & 7.34 & \\
\hline & $U$ & 1 & & \\
\hline \multirow[t]{2}{*}{ sox2 antibody } & $<M+2 S D$ & 42 & 8.68 & 0.3 \\
\hline & $\geq M+2 S D$ & 17 & 7.85 & \\
\hline \multirow[t]{2}{*}{ SOX2 IHC intensity ${ }^{* *}$} & $0-1$ & 25 & 7.39 & 0.98 \\
\hline & $2-3$ & 30 & 10.65 & \\
\hline \multirow[t]{2}{*}{ SOX2 IHC frequency } & $<5 \%$ & 16 & 25.87 & 0.12 \\
\hline & $\geq 5 \%$ & 39 & 7.39 & \\
\hline \multirow[t]{2}{*}{ SOX2 IHC frequency } & $<20 \%$ & 24 & 7.4 & 0.11 \\
\hline & $\geq 20 \%$ & 31 & 7.86 & \\
\hline \multirow[t]{2}{*}{ SOX2 IHC frequency } & $<40 \%$ & 29 & 7.39 & 0.43 \\
\hline & $\geq 40 \%$ & 26 & 9.68 & \\
\hline
\end{tabular}

*U: unknown. ${ }^{* *}$ Tumor tissue sections evaluations were available from 55 patients.

tumors were classified based on whether they contained positively staining cells below and above a cut off of 5, 20 or $40 \%$ of the total tissue (Table 1). When evaluated for intensity of staining, all 13 patients with no SOX2 expression in their tumors were found to be seronegative for SOX2 antibodies. However, while only 2 of 12 patients with weak ("1") staining had antibodies against SOX2, 14 of the 30 patients whose tumors contained intensely staining cells ("2-3") were seropositive for anti-SOX2 $(\mathrm{p}=0.017)$; suggesting that strong SOX2 expression, even if focal, might suffice in inducing an immune response against this antigen (Table 4). The mean $\mathrm{H}$-score for SOX2 seropositive tumors was larger (156.8) than that for seronegatives (110.6), however, the difference was not statistically significant $(\mathrm{p}=0.25$ : two sided t-test). 
Table 2 SOX2 antibody and protein staining characteristics of SCLC patients

\begin{tabular}{|c|c|c|c|c|}
\hline Patients & SOX2 Ab (OD405) & SOX2 staining frequency (\%) & SOX2 staining intensity & H-score \\
\hline AGH-KHA-04 & 4 & 2 & 2 & 6 \\
\hline AGH-KHA-56 & 3.93 & 2 & 3 & 8 \\
\hline AGH-KHA-46 & 3.87 & $U E^{*}$ & UE & UE \\
\hline AGH-KHA-38 & 3.84 & 95 & 3 & 380 \\
\hline AGH-KHA-74 & 3.78 & 100 & 3 & 400 \\
\hline AGH-KHA-71 & 3.77 & 5 & 2 & 15 \\
\hline AGH-KHA-48 & 3.66 & 30 & 2 & 90 \\
\hline AGH-KHA-62 & 3.62 & 45 & 2 & 135 \\
\hline AGH-KHA-73 & 3.06 & 10 & 3 & 40 \\
\hline AGH-KHA-87 & 2.93 & 5 & 2 & 15 \\
\hline AGH-KHA-59 & 2.83 & 90 & 3 & 360 \\
\hline AGH-KHA-77 & 2.74 & 30 & 2 & 90 \\
\hline AGH-KHA-96 & 2.7 & 60 & 1 & 120 \\
\hline AGH-KHA-39 & 2.42 & 90 & 3 & 360 \\
\hline AGH-KHA-37 & 1.98 & 10 & 1 & 20 \\
\hline AGH-KHA-21 & 1.97 & 50 & 2 & 150 \\
\hline AGH-KHA-32 & 1.93 & 80 & 3 & 320 \\
\hline AGH-KHA-93 & 1.78 & 2 & 1 & 4 \\
\hline AGH-KHA-76 & 1.68 & 0 & 0 & 0 \\
\hline AGH-KHA-81 & 1.28 & 5 & 1 & 10 \\
\hline AGH-KHA-28 & 1.23 & 0 & 0 & 0 \\
\hline AGH-KHA-90 & 1.2 & 80 & 2 & 240 \\
\hline AGH-KHA-17 & 1.2 & 0 & 0 & 0 \\
\hline AGH-KHA-66 & 1.19 & 0 & 0 & 0 \\
\hline AGH-KHA-75 & 1.18 & 25 & 1 & 50 \\
\hline AGH-KHA-80 & 1.15 & UE & UE & UE \\
\hline AGH-KHA-11 & 1.09 & 20 & 2 & 60 \\
\hline AGH-KHA-29 & 1.09 & 50 & 2 & 150 \\
\hline AGH-KHA-86 & 1.08 & 5 & 1 & 10 \\
\hline AGH-KHA-95 & 1.07 & 50 & 1 & 100 \\
\hline AGH-KHA-89 & 1.04 & 90 & 2 & 270 \\
\hline AGH-KHA-78 & 1.03 & 0 & 0 & 0 \\
\hline AGH-KHA-70 & 1.03 & 20 & 1 & 40 \\
\hline AGH-KHA-67 & 1.01 & 80 & 2 & 240 \\
\hline AGH-KHA-45 & 0.95 & 0 & 0 & 0 \\
\hline AGH-KHA-68 & 0.92 & 95 & 3 & 380 \\
\hline AGH-KHA-69 & 0.87 & 5 & 1 & 10 \\
\hline AGH-KHA-91 & 0.85 & 40 & 2 & 120 \\
\hline AGH-KHA-88 & 0.84 & 0 & 0 & 0 \\
\hline AGH-KHA-94 & 0.81 & 10 & 1 & 20 \\
\hline AGH-KHA-33 & 0.79 & 0 & 0 & 0 \\
\hline AGH-KHA-79 & 0.76 & 90 & 3 & 360 \\
\hline AGH-KHA-61 & 0.76 & 90 & 3 & 360 \\
\hline AGH-KHA-82 & 0.72 & 0 & 0 & 0 \\
\hline
\end{tabular}


Table 2 SOX2 antibody and protein staining characteristics of SCLC patients (Continued)

\begin{tabular}{|c|c|c|c|c|}
\hline AGH-KHA-57 & 0.68 & UE & UE & UE \\
\hline AGH-KHA-53 & 0.65 & 70 & 2 & 210 \\
\hline AGH-KHA-55 & 0.65 & 70 & 2 & 210 \\
\hline AGH-KHA-15 & 0.64 & 0 & 0 & 0 \\
\hline AGH-KHA-40 & 0.64 & 60 & 2 & 180 \\
\hline AGH-KHA-64 & 0.63 & 70 & 2 & 210 \\
\hline AGH-KHA-72 & 0.61 & 40 & 1 & 80 \\
\hline AGH-KHA-24 & 0.55 & 90 & 3 & 360 \\
\hline AGH-KHA-51 & 0.55 & 60 & 3 & 240 \\
\hline AGH-KHA-43 & 0.54 & 0 & 0 & 0 \\
\hline AGH-KHA-12 & 0.52 & UE & UE & UE \\
\hline AGH-KHA-50 & 0.5 & 0 & 0 & 0 \\
\hline AGH-KHA-52 & 0.48 & 70 & 3 & 280 \\
\hline AGH-KHA-34 & 0.46 & 60 & 1 & 120 \\
\hline AGH-KHA-49 & 0.45 & 0 & 0 & 0 \\
\hline
\end{tabular}

*UE: Unable to evaluate. Seropositive sera (OD405 > 1,799) are indicated in bold font.

\section{Discussion}

The illumination of the mechanisms underlying antitumor immune responses is critical as such responses can be ultimately boosted if their beneficial affect can be proven. To our knowledge, this is the first study where autologous anti-tumor antibody responses against SOX2 have been correlated with tumor antigen expression in SCLC. It is known that autologous antibodies can be elicited against either upregulated, mutated or foreign proteins [17]. SOX2 is amplified and thus upregulated, but not mutated in SCLC [18]. In patients with monoclonal gammopathy of undetermined significance (MGUS), anti-SOX2 T cell responses were found to be directed against a very small percentage of tumor cells which were of the clonogenic type [13]. In the same study, patients with anti-SOX2 $\mathrm{T}$ cells showed significantly better overall survival. In contrast to the case with MGUS, in SCLC, SOX2 immune responses, as measured by the presence of antibody, have been observed to correlate with better outcome only in one of the three cohorts studied so far [10-12]. We believe there could be several explanations for this. Firstly, as demonstrated in the MGUS study, antiSOX2 T-cell and antibody responses do not overlap completely; therefore, if $\mathrm{T}$-cell responses determine outcome more so than antibodies, than this awaits to
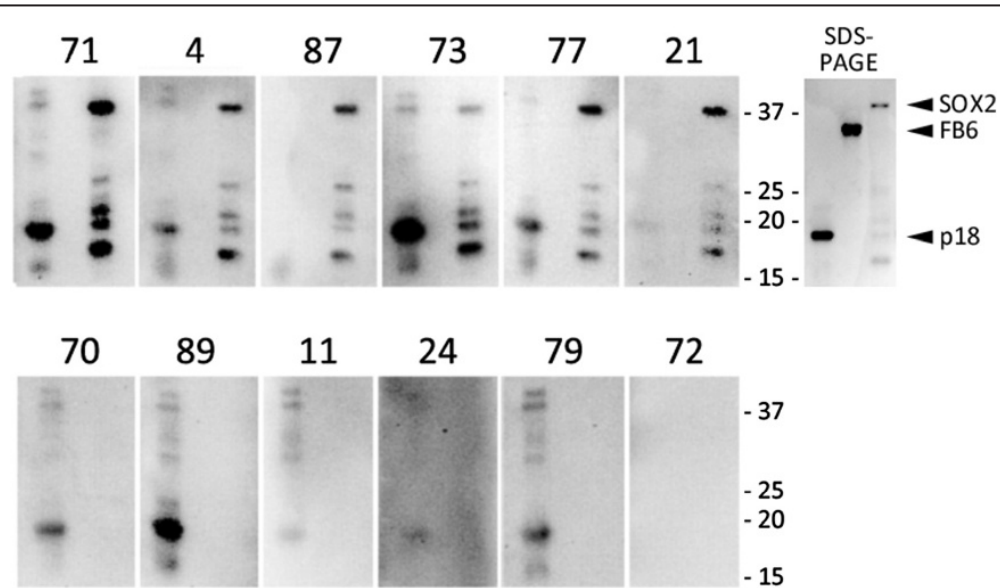

Figure 1 SOX2 Western results confirm ELISA data. Sera from patients with anti-SOX2 antibodies according to ELISA (\#71, 4, 87, 73, 77, 21) and those without antibodies $(\# 70,89,11,24,79,17)$ were analyzed by Western blotting for reactivity against EBV p18 protein (positive control, 18kD), FB6 (a negative control, 35kD), and SOX2 (38kD), run in the first, second and third lanes of each gel, respectively. Coomassie blue staining of SDS-PAGE analysis of the proteins used for Western is shown on the upper right. Smaller molecular weight bands observed for SOX2 are due to premature translation termination. 
Table 3 SOX2 antibody correlates with clinical stage

\begin{tabular}{lllll}
\hline & & \multicolumn{2}{c}{ SOX2 $\mathbf{A b}$} & P (chi.sq.) \\
\cline { 3 - 4 } & & $(-)$ & $(+)$ & \\
\hline Stage & Limited & 16 & 12 & 0.05 \\
& Extensive & 22 & 5 & \\
\hline
\end{tabular}

be demonstrated for SCLC. Secondly, no study to date has shown an association between worse outcome, or prognosis with SOX2 seropositivity. In contrast, SOX2 protein expression has been related to more aggressive tumors in several studies $[4,19-21]$ and the upregulation of this gene is known to enhance tumor cell proliferation [18]. In addition, SOX2 overexpression has been shown to be essential for lung cancer stem cell function [22,23]. It is possible that antibody responses are associated with improved outcome, but given the fact that SOX2 expression has the opposite effect, the two cancel out each other. Larger and comprehensive studies might further clarify these matters.

A very strong evidence that anti-tumor immune responses can effectively eliminate selected cells in humans comes from the observation that anti-tumor responses against antigens expressed in tumors but also in normal tissues, and in particular in Purkinje cells of the cerebellum, are able to completely eliminate these cells, without destroying surrounding tissues [24]. The amount of antigen expressed by a given cell has been shown to determine the type of $\mathrm{T}$ cell response directed against it [25]. HER-2/neu specific immunity, for example, has been shown to depend on the

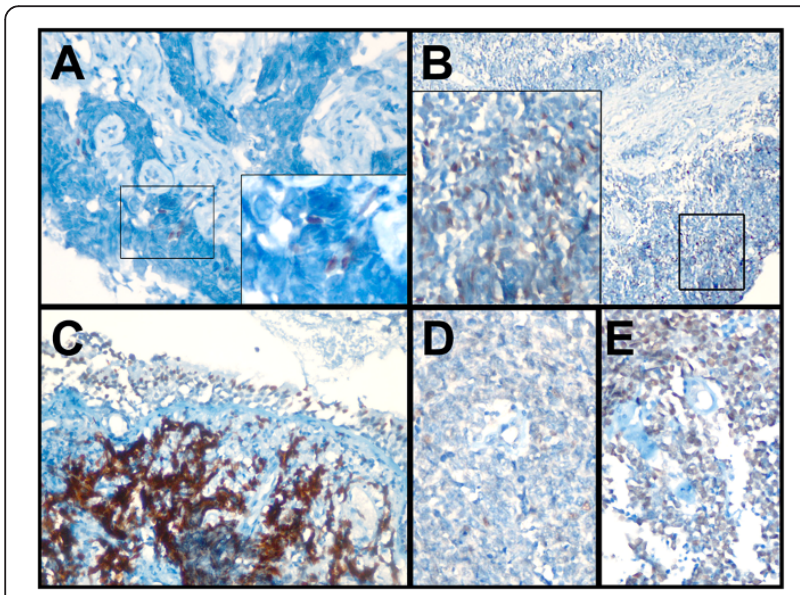

Figure 2 SOX2 staining is heterogeneous. Tumors from three seropositive (A-C; AGH-KHA-4, 71, and 21 respectively) and two seronegative patients (D \& E; AGH-KHA-72, and 89, respectively) are shown. SOX2 staining is predominantly nuclear. In addition to tumor cells, staining of bronchiolar epithelial cells was also observed (C). See Table 2 for details of immunohistochemical evaluation and SOX2 seropositivity testing results.
Table 4 SOX2 antibody correlates with intensity of SOX2 protein expression

\begin{tabular}{lllll}
\hline & & \multicolumn{2}{c}{ SOX2 $\mathbf{A b}$} & P (chi.sq.) \\
\cline { 3 - 4 } & & $(-)$ & $\mathbf{( + )}$ & \\
\hline SOX2 IHC intensity & $0-1$ & 23 & 2 & 0.017 \\
& $2-3$ & 16 & 14 & \\
\hline
\end{tabular}

antigens' expression level [26]. Therefore, it is possible that only cells with intense SOX2 expression were able to induce immune responses against them in the cohort we studied, potentially resulting in their loss, similar to the case with Purkinje cells in patients with anti-HuD antibodies. The fact that in our study SOX2 seropositive patients' tumors on occasion contained very few cells could be reflecting the fact that such tumors undergo immune-editing [27], and reach a state of equilibrium between the tumor and the immune response following a loss of most SOX2 expressing cells [28]. Another explanation could be that those cells in tumors from patients who are seropositive represent clonogenic cells which elicit an immune response as observed for MGUS patients [13]. In glioma the intensity and not the frequency of SOX2 expression was shown to be an indicator of a more stem-like phenotype [29]. On the other hand, the weak but diffuse staining in a number of tumors we studied might reflect the presence of SOX2 expressing non-clonogenic cells. This is likely as we and others have found morphologically normal bronchial epithelium to be frequently positive for SOX2 [30], and is also supported by experiments showing that the transfection of a second gene in addition to SOX2 is required for tumorigenic transformation in some models [31,32].

\section{Conclusions}

We report, for the first time, a relation between SOX2 protein expression characteristics and anti-SOX2 antibody responses in patients with SCLC. Although we find no correlation between outcome or clinical measures with frequency or intensity of SOX2 expression, we observe that SOX2 seropositivity associates with better prognosis. Tumors from patients with SOX2 antibody generally contain strongly staining cells, in contrast to tumors from seronegative patients. This suggests that the intensity of SOX2 expression might be critical in eliciting an anti-SOX2 immune response. The fact that several tumors have very low numbers of such cells suggests that SOX2 expressing cells could have been eliminated over the course of disease, which is in support of active tumor immune-surveillance and immune-editing in these patients. 


\section{Additional file}

Additional file 1: Figure S1. Scatter dot plot of SOX2 ELISA. The median values for small cell lung cancer (SCLC) and healthy control sera (CTR), as well as the cut-off for seropositivity (dotted line) are shown. Figure S2. Kaplan-Meier analysis of patients stratified according to SOX2 seropositivity. Although seropositive patients show a trend for better overall survival the difference, as calculated by the log-rank test, is insignificant $(p=0.3)$.

\section{Competing interests}

The authors declare that they have no competing interests. AOG holds a patent on the use of SOX2 and related molecules (US 7314721).

\section{Authors' contributions}

Conception and design: SA, HB, FD, BV, AOG. Data acquisition: SA, HB, SS, FD, ASY. Data analysis/interpretation: SA, AP, HB, SS, FD, AOG. Drafting and final approval: SA, HB, SS, AP, BV, FD, ASY, AOG. All authors read and approved the final manuscript.

\section{Acknowledgements}

We thank Ms. Elcin Sehitoglu and Ms. Elif Ugurel in helping with the collection of sera from healthy volunteers. This work was supported by a grant (109S339) from The Scientific and Technological Research Council of Turkey (TUBITAK), and from the E.C. (FP6, MCRIG, Lungcaabs) to AOG, and a graduate fellowship from TUBITAK-BIDEP to SA.

\section{Author details}

${ }^{1}$ Department of Molecular Biology and Genetics, Bilkent University, Ankara 06800, Turkey. ${ }^{2}$ Department of Thoracic Medicine, Atatürk Chest Diseases and Chest Surgery Education and Research Hospital, Ankara, Turkey. ${ }^{3}$ Department of Pathology, Ankara University, Ankara, Turkey. ${ }^{4}$ Department of Pathology, Atatürk Chest Diseases and Chest Surgery Education and Research Hospital, Ankara, Turkey. ${ }^{5}$ Department of Genetics, Institute for Experimental Medicine, Istanbul University School of Medicine, Istanbul, Turkey.

Received: 27 January 2014 Accepted: 4 June 2014

Published: 7 June 2014

\section{References}

1. Uchikawa M, Yoshida M, Iwafuchi-Doi M, Matsuda K, Ishida Y, Takemoto T, Kondoh H: B1 and B2 Sox gene expression during neural plate development in chicken and mouse embryos: universal versus species-dependent features. Dev Growth Differ 2011, 53(6):761-771.

2. Ishii Y, Rex M, Scotting PJ, Yasugi S: Region-specific expression of chicken Sox 2 in the developing gut and lung epithelium: regulation by epithelial-mesenchymal interactions. Dev Dyn 1998, 213(4):464-475.

3. Jung YW, Hysolli E, Kim KY, Tanaka Y, Park IH: Human induced pluripotent stem cells and neurodegenerative disease: prospects for novel therapies. Curr Opin Neurol 2012, 25(2):125-130.

4. Sholl LM, Barletta JA, Yeap BY, Chirieac LR, Hornick JL: Sox2 protein expression is an independent poor prognostic indicator in stage I lung adenocarcinoma. Am J Surg Pathol 2010, 34(8):1193-1198.

5. Sholl LM, Long KB, Hornick JL: Sox2 expression in pulmonary non-small cell and neuroendocrine carcinomas. Appl Immunohistochem Mol Morphol 2010, 18(1):55-61.

6. Wilbertz T, Wagner P, Petersen K, Stiedl AC, Scheble VJ, Maier S, Reischl M, Mikut R, Altorki NK, Moch H, Fend F, Staebler A, Bass AJ, Meyerson M, Rubin MA, Soltermann A, Lengerke C, Perner S: SOX2 gene amplification and protein overexpression are associated with better outcome in squamous cell lung cancer. Mod Pathol 2011, 24(7):944-953.

7. Yang F, Gao Y, Geng J, Qu D, Han Q, Qi J, Chen G: Elevated expression of SOX2 and FGFR1 in correlation with poor prognosis in patients with small cell lung cancer. Int J Exp Pathol 2013, 6(12):2846-2854.

8. Jongeneel V: Towards a cancer immunome database. Cancer Immun 2001, 1:3

9. Gure AO, Stockert E, Scanlan MJ, Keresztes RS, Jager D, Altorki NK, Old LJ, Chen YT: Serological identification of embryonic neural proteins as highly immunogenic tumor antigens in small cell lung cancer. Proc Natl Acad Sci U S A 2000, 97(8):4198-4203.
10. Titulaer MJ, Klooster R, Potman M, Sabater L, Graus F, Hegeman IM, Thijssen PE, Wirtz PW, Twijnstra A, Smitt PA, Van Der Maarel SM, Verschuuren JJ: SOX antibodies in small-cell lung cancer and Lambert-Eaton myasthenic syndrome: frequency and relation with survival. J Clin Oncol 2009, 27(26):4260-4267.

11. Maddison P, Thorpe A, Silcocks P, Robertson JF, Chapman CJ: Autoimmunity to SOX2, clinical phenotype and survival in patients with small-cell lung cancer. Lung Cancer 2010, 70(3):335-339.

12. Vural B, Chen LC, Saip P, Chen YT, Ustuner Z, Gonen M, Simpson AJ, Old LJ, Ozbek U, Gure AO: Frequency of SOX Group B (SOX1, 2, 3) and ZIC2 antibodies in Turkish patients with small cell lung carcinoma and their correlation with clinical parameters. Cancer 2005, 103(12):2575-2583.

13. Spisek R, Kukreja A, Chen LC, Matthews P, Mazumder A, Vesole D, Jagannath $S$, Zebroski HA, Simpson AJ, Ritter G, Durie B, Crowley J, Shaughnessy JD Jr, Scanlan MJ, Gure AO, Barlogie B, Dhodapkar MV: Frequent and specific immunity to the embryonal stem cell-associated antigen SOX2 in patients with monoclonal gammopathy. J Exp Med 2007, 204(4):831-840.

14. Lessey BA, Killam AP, Metzger DA, Haney AF, Greene GL, McCarty KS Jr: Immunohistochemical analysis of human uterine estrogen and progesterone receptors throughout the menstrual cycle. J Clin Endocrinol Metabol 1988, 67(2):334-340.

15. Sagman U, Feld R, Evans WK, Warr D, Shepherd FA, Payne D, Pringle J, Yeoh J, DeBoer G, Malkin A, Ginsberg R: The prognostic significance of pretreatment serum lactate dehydrogenase in patients with small-cell lung cancer. J Clin Oncol 1991, 9(6):954-961.

16. Sagman U, Maki E, Evans WK, Warr D, Shepherd FA, Sculier JP, Haddad R Payne D, Pringle JF, Yeoh JL, C A, DeBoer G, McKinney R, G R, Feld R: Small-cell carcinoma of the lung: derivation of a prognostic staging system. J Clin Oncol 1991, 9(9):1639-1649.

17. Chen YT, Scanlan MA, Obata Y, Old LJ: Identification of Human Tumor Antigens by Serological Expression Cloning. In Principles and Practice of the Biological Therapy of Cancer. Edited by Rosenberg SA. Philadephia: Lippincott Williams \& Wilkins; 2000:557-570.

18. Rudin CM, Durinck S, Stawiski EW, Poirier JT, Modrusan Z, Shames DS, Bergbower EA, Guan Y, Shin J, Guillory J, Rivers CS, Foo CK, Bhatt D, Stinson J, Gnad F, Haverty PM, Gentleman R, Chaudhuri S, Janakiraman V, Jaiswal BS, Parikh C, Yuan W, Zhang Z, Koeppen H, Wu TD, Stern HM, Yauch RL, Huffman KE, Paskulin DD, Illei PB, et al: Comprehensive genomic analysis identifies SOX2 as a frequently amplified gene in small-cell lung cancer. Nat Genet 2012, 44(10):1111-1116.

19. Wang Q, He W, Lu C, Wang Z, Wang J, Giercksky KE, Nesland JM, Suo Z: Oct3/4 and Sox2 are significantly associated with an unfavorable clinical outcome in human esophageal squamous cell carcinoma. Anticancer Res 2009, 29(4):1233-1241.

20. Saigusa S, Tanaka K, Toiyama Y, Yokoe T, Okugawa Y, loue Y, Miki C, Kusunoki M: Correlation of CD133, OCT4, and SOX2 in rectal cancer and their association with distant recurrence after chemoradiotherapy. Ann Surg Oncol 2009, 16(12):3488-3498.

21. Du L, Yang Y, Xiao X, Wang C, Zhang X, Wang L, Zhang X, Li W, Zheng G, Wang S, Dong Z: Sox2 nuclear expression is closely associated with poor prognosis in patients with histologically node-negative oral tongue squamous cell carcinoma. Oral Oncol 2011, 47(8):709-713.

22. Xiang R, Liao D, Cheng T, Zhou H, Shi Q, Chuang TS, Markowitz D, Reisfeld RA, Luo Y: Downregulation of transcription factor SOX2 in cancer stem cells suppresses growth and metastasis of lung cancer. Br J Cancer 2011, 104(9):1410-1417.

23. Nakatsugawa M, Takahashi A, Hirohashi $Y$, Torigoe $T$, Inoda S, Murase M, Asanuma H, Tamura Y, Morita R, Michifuri Y, Kondo T, Hasegawa T, Takahashi H, Sato N: SOX2 is overexpressed in stem-like cells of human lung adenocarcinoma and augments the tumorigenicity. Lab Invest 2011, 91(12):1796-1804

24. Peterson K, Rosenblum MK, Kotanides H, Posner JB: Paraneoplastic cerebella degeneration. I. A clinical analysis of 55 anti-Yo antibody-positive patients. Neurology 1992, 42(10):1931-1937.

25. Daniels MA, Teixeiro E, Gill J, Hausmann B, Roubaty D, Holmberg K, Werlen G, Hollander GA, Gascoigne NR, Palmer E: Thymic selection threshold defined by compartmentalization of Ras/MAPK signalling. Nature 2006, 444(7120):724-729.

26. Goodell V, Waisman J, Salazar LG, de la Rosa C, Link J, Coveler AL, Childs JS, Fintak PA, Higgins DM, Disis ML: Level of HER-2/neu protein expression in 
breast cancer may affect the development of endogenous HER-2/neu-specific immunity. Mol Cancer Ther 2008, 7(3):449-454.

27. Dunn GP, Old $L$, Schreiber RD: The three Es of cancer immunoediting. Annu Rev Immunol 2004, 22:329-360.

28. Koebel CM, Vermi W, Swann JB, Zerafa N, Rodig SJ, Old LJ, Smyth MJ, Schreiber RD: Adaptive immunity maintains occult cancer in an equilibrium state. Nature 2007, 450(7171):903-907.

29. Velpula KK, Dasari VR, Tsung AJ, Dinh DH, Rao JS: Cord blood stem cells revert glioma stem cell EMT by down regulating transcriptional activation of Sox2 and Twist1. Oncotarget 2011, 2(12):1028-1042.

30. Chen S, Xu Y, Chen Y, Li X, Mou W, Wang L, Liu Y, Reisfeld RA, Xiang R, $L V D, L i N$ : SOX2 gene regulates the transcriptional network of oncogenes and affects tumorigenesis of human lung cancer cells. PLOS ONE 2012, 7(5):e36326.

31. Park IH, Zhao R, West JA, Yabuuchi A, Huo H, Ince TA, Lerou PH, Lensch MW, Daley GQ: Reprogramming of human somatic cells to pluripotency with defined factors. Nature 2008, 451(7175):141-146.

32. Takahashi K, Yamanaka S: Induction of pluripotent stem cells from mouse embryonic and adult fibroblast cultures by defined factors. Cell 2006, 126(4):663-676.

doi:10.1186/1472-6890-14-24

Cite this article as: Atakan et al:: Autologous anti-SOX2 antibody responses reflect intensity but not frequency of antigen expression in small cell lung cancer. BMC Clinical Pathology 2014 14:24.

\section{Submit your next manuscript to BioMed Central and take full advantage of:}

- Convenient online submission

- Thorough peer review

- No space constraints or color figure charges

- Immediate publication on acceptance

- Inclusion in PubMed, CAS, Scopus and Google Scholar

- Research which is freely available for redistribution 